УДК 349.222

https://doi.org/10.34142/23121661.2021.34.01

orcid.org/0000-0003-2509-865X

(C) Головань Т.Г., 2021

\title{
Т.Г. Головань
}

\section{ГЕНЕЗА СОЦІАЛЬНОГО ДІАЛОГУ}

\section{T. Holovan}

\section{GENESIS OF SOCIAL DIALOGUE}

\begin{abstract}
Анотація. У статті розглядаються питання становлення соціального діалогу в Україні в контексті необхідності проведення подальших наукових досліджень для формування доктрини соціального діалогу. Оцінюючи досягнення сучасної науки трудового права в сфері соціального діалогу, можна констатувати відсутність комплексних досліджень ідей соціального діалогу, передумов їхнього виникнення, аналізу факторів, що сприяють їхній появі та розвитку, еволюції соціального діалогу на території України, аналізу концепції соціального діалогу як елементу становлення соціально-трудових відносин.

Ключові слова: соціальний діалог, соціальне партнерство, ідеї соціального діалогу, еволюція теорії соціального діалогу, інституціоналізація соціального діалогу, соціальнотрудові відносини.
\end{abstract}

Аннотация. В статье рассматриваются вопросы становления социального диалога в Украине в контексте необходимости проведения дальнейших научных исследований для формирования доктрины социального диалога. Оценивая достижения современной науки трудового права в сфере социального диалога, можно констатировать отсутствие комплексных исследований идей социального диалога, предпосылок их возникновения, анализа факторов, способствующих их появлению и развитию, эволюции социального диалога на территории Украины, анализа концепции социального диалога как элемента становления социально-трудовых отношений.

Ключевые слова: социальный диалог, социальное партнерство, идеи социального диалога, эволюция теории социального диалога, институционализация социального диалога, социально-трудовые отношения.

Abstract. The article discusses the issues of the formation of social dialogue in Ukraine in the context of the need for further scientific research to form the doctrine of social dialogue. Evaluating the achievements of the modern science of labour law in the field of social dialogue, it can be stated that there is no research into the ideas of social dialogue, the prerequisites for their emergence, analysis of the factors contributing to their emergence and development, the evolution of social dialogue on the territory of Ukraine, analysis of the concept of social dialogue as an element of the formation of social and labour relations.First of all social dialogue until its own age and become "the basis and change of mind to accept any government decisions in the country, but 
also from economic and social changes in Ukraine", it is necessary to go through an, discovering clearances and openings of nobles and usunions, advancing international information, scientific advice of all elements of social dialogue. In order to accelerate these processes, the need for the activation of scientific advances in this region, some examples of the implementation of any institutes, as not to blame the science of science, is doomed to failure.

Key words: social dialogue, social partnership, ideas of social dialogue, evolution of the theory of social dialogue, institutionalization of social dialogue, social and labour relations.

Постановка проблеми. На сьогоднішній день в умовах загострення соціальних проблем доволі актуальним є дослідження питань упровадження ефективного соціального діалогу в Україні. Адже саме завдяки соціальному діалогу, шляхом узгодження соціально-економічних інтересів його сторін, можна досягти стабільності в суспільстві та значного прогресу в соціальноекономічній сфері. Водночас соціальний діалог стає досить популярним інструментом урегулювання соціально-трудових відносин.

Д. М. Горєлов зазначає, що «Одним з випробуваних інструментів урегулювання соціально-трудових відносин, вирішення широкого кола соціальноекономічних проблем $\epsilon$ соціальний діалог - процес визначення та зближення позицій, досягнення спільних домовленостей та прийняття узгоджених рішень сторонами, які представляють інтереси працівників, роботодавців, органів виконавчої влади та органів місцевого самоврядування» [2]. Однак, на жаль, «соціальний діалог в країні загалом, у його цивілізованій формі знаходиться на початковій стадії розвитку» [3].

Основною перешкодою на шляху до формування ефективної системи соціального діалогу в Україні «є історичні та ідеологічні стереотипи, що дісталися у спадок соціальним партнерам від попереднього режиму». Перш ніж соціальний діалог досягне своєї мети і стане «основою та передумовою прийняття будь-яких владних рішень на рівні держави щодо будь-яких економічних і соціальних змін в Україні» [4], необхідно пройти довгий шлях аналізу наявних помилок, визначення індикаторів та чинників неефективності, виявлення прогалин і розробки шляхів їхнього усунення, дослідження міжнародного досвіду, наукового обгрунтування всіх елементів соціального діалогу.

3 метою прискорення зазначених процесів виникає необхідність в активізації наукових досліджень в цій галузі, оскільки реалізація будь-яких інститутів, які не мають наукового підгрунтя, приречена на провал.

Аналіз останніх досліджень. Щодо грунтовного дослідження питань становлення соціального діалогу в Україні можна зазначити, що ці питання не отримали належної уваги. Правові аспекти соціального діалогу в Україні, зокрема, принципи соціального діалогу, форми та рівні соціального діалогу досліджувались такими вченими, як В. В. Жернаков, Г. І. Чанишева, С. М. При- 
липко, О. М. Ярошенко, О. А. Трюхан, О. О. Коваленко, М. О. Міщук, В. В. Яцишин. Однак комплексні дослідження генези соціального діалогу відсутні.

Формулювання мети статті (постановка завдання). Метою цієї наукової статті є дослідження та розгляд питання становлення соціального діалогу в Україні в контексті необхідності проведення подальших наукових досліджень для формування доктрини соціального діалогу.

Виклад основного матеріалу. «Практично за всіма найважливішими соціальними показниками світового цивілізаційного розвитку Україна впритул підійшла до небезпечної межі: основні соціальні ризики - бідність, майнова диференціація населення, відстороненість значної кількості громадян від суспільного життя, обмеження їхнього доступу до освіти, медицини і культури досягли масштабів, які можуть мати реальну загрозу для національної безпеки держави. Загалом аналіз ефективності вітчизняної моделі соціального діалогу в Україні свідчить про наявність комплексу проблем, актуальних як для суспільства, так і для держави» [5]. У нашій державі «соціальний діалог на національному, галузевому, територіальному, місцевому та локальному рівнях знаходиться в стадії становлення. Сформована за роки незалежності України правова й організаційна база не забезпечує бажаного ефекту соціального діалогу» [5].

Аналізуючи становлення соціального діалогу в Україні, можна з упевненістю говорити про те, що його впровадження здійснюється методом «спроб і помилок». Усі інституційні зміни проводяться без аналізу попереднього досвіду.

Не можна не погодитися з О.М. Петроє, яка говорить про те, що 3 досвіду зарубіжних країн можна зробити висновок про існування певного шляху розвитку соціального діалогу: від ідеї до соціальної інституції. «Шляхом інституціоналізації соціального діалогу йдуть усі без винятку європейські держави, досвід яких використовує Україна. Успішність розвитку соціального діалогу в Україні в основному залежить від ефективності державної політики в цій сфері, розвитку культури» [2]. Тільки за умови детального вивчення розвитку соціального діалогу від ідеї до соціальної інституції можна виокремити певні закономірності, умови, етапи, за допомогою яких є змога чітко сформувати розуміння ефективної системи соціального діалогу.

Загалом виникнення партнерських відносин пов'язують із соціальноекономічними та політичними змінами, які відбувалися протягом XIX-XX ст. Зміни були пов'язані з розвитком капіталістичних відносин і масштабними перетвореннями політичних систем. Але первинні ідеї соціального діалогу почали зароджуватися набагато раніше. Ідеї соціального діалогу виявлялися в різних формах і полягали в постійній взаємодії роботодавця й працівника. 
Говорячи про становлення інституту соціального діалогу на території України, виокремлюють кілька історичних етапів.

Перший етап охоплює початок XIX ст. - початок XX ст. Цей період характеризується активним розвитком аграрних регіонів, відсутністю промисловості й промислового пролетаріату, розвитком масового кооперативного руху. Саме в цей період почали зароджуватися первинні ідеї соціального партнерства, які проявлялися у вигляді створення товариств взаємної допомоги. Прикладом такого суспільства називають «Суспільство взаємної допомоги учасників друкарської справи», яке було створено в місті Львові 1817 р. Це суспільство намагалося організувати й забезпечити вирішення матеріальних проблем і проблем правового захисту своїх учасників. Водночас профспілковий рух був незначним.

Згодом стали розвиватися споживчі товариства, що стрімко створювалися в багатьох містах України впродовж 1860-х рр. Метою створення таких товариств було надання грошової допомоги його членам, організація пільгового медичного обслуговування і т. д. Саме такі суспільства і є прототипом ідеї соціального партнерства.

I вже на цій основі в період революції виник один із суб'єктів соціального діалогу, який є найбільш активним і зацікавленим, - професійна спілка.

Другий етап охоплює початок XX ст. і закінчується проголошенням незалежності України 1991 р. Це найбільш тривалий етап, який охопив безліч історичних подій. Цей період характеризується появою передумов демократизації соціально-трудових відносин. Саме після революції 1917 р. стали з'являтися перші спроби врегулювання трудових конфліктів, що виникають між роботодавцями та найманими працівниками, за допомогою органів примирення, таких як комісаріати праці Тимчасового уряду, третейські суди, професійні спілки, відділи праці рад робітничих депутатів.

Істотну роль у цей період відіграли Генеральний секретаріат праці, діяльність якого будувалася на принципах свободи коаліції, примирення сторін i забезпечення колективних умов праці, і Департамент взаємовідносин між працею і капіталом, до повноважень якого належало вирішення конфліктів, що виникають на підприємствах та в установах. Значне поширення отримали колективні договори.

Саме для цього періоду $є$ характерним стрімкий розвиток соціальноекономічних відносин, трансформація соціально-трудових відносин, створення передумов виникнення соціально-партнерських відносин. Безумовно, усьому цьому сприяла низка історичних подій, які відігравали роль каталізатора. Україна пройшла складний шлях від реалізації ідеї класової боротьби й установлення диктатури пролетаріату до демократизації виробничих відносин і розвитку ідей соціального партнерства. 
Третій етап охоплює період з 1991 р. і дотепер. Після проголошення незалежності України основним вектором ії розвитку стала інтеграція в європейське співтовариство. Свроінтеграційні ідеї є усвідомленим і стратегічним вибором українського суспільства. Саме євроінтеграція $\epsilon$ пріоритетним напрямом у реалізації зовнішньої політики України. Говорячи про необхідність і пріоритетність реалізації процесу інтеграції, необхідно усвідомлювати, що іiі ефективність залежить від наявності певних умов, зокрема змін законодавчої бази, упровадження стандартів і норм Європейського Союзу, реалізації державної політики. Україна стоїть на шляху розвитку соціальних і політичних процесів.

Розвиток економіки й суспільства можливі тільки за умови розширення соціальної бази для зміцнення демократичних інститутів і послідовного розвитку громадянського суспільства. У цьому випадку реальним пріоритетом розвитку держави й економіки має бути забезпечення гідного життя громадян. Одним із шляхів забезпечення цих умов є створення дієвої системи соціального діалогу.

Сучасний етап розвитку України вимагає гармонізації інтересів держави, роботодавців і працівників. Необхідно враховувати соціальну напругу в Україні, викликану обговоренням змін у трудовому законодавстві.

Після проголошення незалежності України почався активний розвиток соціального партнерства, оскільки перехід до активного розвитку ринкової економіки призвів до зниження рівня життя i, відповідно, до зниження рівня оплати праці.

Серйозним поштовхом для обговорення можливостей упровадження соціального діалогу між представниками органів державної влади, роботодавців і працівників стали страйки, протести та економічна криза.

Саме в цей період почався процес активного становлення соціального партнерства. Завданням держави стало прийняття на себе ініціативи врегулювання конфлікту, який зачіпає загальнонаціональні інтереси й права людини в разі недосягнення згоди між суб'єктами соціального партнерства. Унаслідок цього відбулося перетворення інституту «колективний договір» радянського трудового права в інститут уже сучасного трудового права «соціальне партнерство», який отримав законодавче закріплення.

Істотним кроком у розвитку соціального партнерства в Україні стало творення Національної ради соціального партнерства, відповідно до Указу Президента України від 08.02.1993 р. № 34/93 «Про Національну раду соціального партнерства».

Указом Президента України від 27.04.1993 р. № 151/93 затверджено Положення про Національну раду соціального партнерства, яким було визначено його статус і принципи діяльності. Національна рада соціального парт- 
нерства була постійним консультативно-дорадчим органом при Президентові України і створювалася 3 метою узгодженого й ефективного вирішення проблемних питань, які періодично виникали в соціально-трудовій сфері.

У складі Національної ради соціального партнерства були представники Кабінету Міністрів України, об’єднань підприємців, професійних спілок. Основними завданнями Національної ради соціального партнерства були узгодження шляхом тристоронніх консультацій позицій сторін у соціальнотрудовій сфері з метою забезпечення поєднання інтересів держави, роботодавців і працівників підприємств, установ та організацій, а також пошук компромісів між соціальними партнерами для запобігання конфліктам.

Наступним важливим кроком стало впровадження та налагодження соціального партнерства в регіонах. Це привело до розвитку галузей промисловості, що у свою чергу сприяло збереженню робочих місць, активній зайнятості населення, збільшенню надання адресної соціальної допомоги.

3 метою подальшого врегулювання процесу вирішення колективних трудових спорів Указом Президента України від 17.11.1998 р. № 1258/98 «Про утворення Національної служби посередництва і примирення» була створена Національна служба посередництва і примирення.

Ця служба стала постійним державним органом, створеним Президентом України для сприяння врегулюванню колективних трудових спорів (конфліктів). Основними завданнями Національної служби посередництва і примирення було забезпечення взаємодії сторін соціально-трудових відносин у процесі врегулювання колективних трудових спорів (конфліктів), що виникли між ними; прогнозування виникнення колективних трудових спорів (конфліктів) та сприяння вчасному їхньому вирішенню; здійснення посередництва й примирення під час вирішення колективних трудових спорів (конфліктів). Зазначений орган не завжди достатньо ефективно виконував свої функції, унаслідок чого Указом Президента України від 29.12.2005 р. № 1871/2005 «Про розвиток соціального діалогу в Україні» була створена Національна тристороння соціально-економічна рада як консультативно-дорадчий орган при Президентові України. Складався він 3 представників Кабінету Міністрів України, всеукраїнських професійних спілок та їхніх об'єднань, всеукраїнських об'єднань організацій роботодавців, які є суб’єктами Генеральної угоди.

Наступним важливим кроком стало прийняття Закону України від 23.12.2010 р. № 2862-IV «Про соціальний діалог в Україні» (далі - Закон про соціальний діалог). Однак, як наслідок, Указом Президента України від 02.04.2011 p. № 347/2011 «Про Національну тристоронню соціально-економічну раду» був створений інший постійний орган - Національну тристоронню соціально-економічну раду. Ухвалення Закону про соціальний діалог, на жаль, не виправдало очікувань. Законодавець підійшов до регулювання сфери 
соціального діалогу формально, що призвело до виникнення проблем у його практичній реалізації. Учені й практики зосереджують увагу на якості та обгрунтованості тримання норм цього Закону, адже він потребує суттєвого доопрацювання. Насамперед необхідне чітке визначення понятійного апарату, що застосовується законодавцем. Крім того, потребує перегляду зміст статті, якою закріплений перелік принципів соціального діалогу. Тільки за умови чіткого нормативно-правового регулювання соціального діалогу в Україні він стане дієвим інструментом розвитку соціально-трудових відносин, допоможе запобігати появі та ефективно вирішувати вже наявні проблеми в сфері праці.

Сучасний етап розвитку України вимагає гармонізації інтересів держави, роботодавців і працівників. Одним із сучасних і ефективних способів забезпечення досягнення рівноваги в суспільстві є соціальний діалог.

Соціальний діалог розглядається як механізм вирішення проблем i як засіб забезпечення соціальної справедливості та економічної ефективності. Він важливий для захисту трудових прав, забезпечення гідної оплати праці, поліпшення умов праці.

Висновки з цуього дослідження й перспективи подальших розвідок у ц̧ьому напрямі. На жаль, наявна система соціального діалогу характеризується низьким рівнем нормативно-правового регулювання, невизначеністю окремих і1 елементів, що призводить до іiі неефективності. Система соціального діалогу в Україні не досягає своєї мети, залишається лише формальною і не забезпечує очікуваного соціально-економічного ефекту.

Ухвалення основного Закону про соціальний діалог не виправдав очікувань. Законодавець підійшов до регулювання сфери соціального діалогу формально, у зв'язку з чим зміст цього Закону викликає постійні правові дискусії. Практика застосування його норм спонукає до наукового пошуку шляхів вирішення наявних проблем, усунення виявлених суперечностей, розробці прогресивних форм і методів соціального діалогу.

У процесі аналізу стану впровадження соціального діалогу в Україні стало абсолютно зрозуміло, що цей інститут $є$ недостатньо дослідженим і на сьогодні існує необхідність у вивченні історії його становлення, аналізі характерних для України закономірностей його розвитку, розробці нових концептуальних теоретичних положень щодо всієї системи соціального діалогу, прогнозів розвитку цього інституту.

\section{Література}

1. Горєлов Д.М. Формування соціального діалогу в сучасних умовах: світовий досвід та українська практика. Київ: НІСД, 2011. 47 с.; 2. Петроє О.М. Соціальний діалог у державному управлінні: європейський досвід та українські реалії. Київ: НАДУ, 2012. 304 с. 3. Соціальний діалог в Україні в контексті підписання угоди про асоціацію - виклики та 
пропозиції / Бюро соціальних та політичних розробок. Київ, 2014. URL: https://bureau.in.ua/ downloads/social-dialogue/Ukraine.pdf.; 4. Давидюк О.О. Соціальна безпека: проблеми теоретичного аналізу та побудови показників. Київ: Абрис, 2002. С. 158-162. 5. Трощинський В.П. Соціальний діалог і соціальне партнерство як засадничі принципи державного управління. Стратегія державної кадрової політики - основа модернізації краӥни: матеріали Всеукр. наук.-практ. конф. за міжнар. участю, Київ, 31 трав. 2012 р.: до 15-річчя галузі науки «Державне управління». Київ: НАДУ, 2012. С. 411-413; 6. Даль В. Толковый словарь живого великорусского языка. Москва: Гос. изд-во иностранных и нац. словарей. Т. 3: П. 1955. 556 с.; 7. Великий тлумачний словник сучасної української мови (з дод. і допов.) / уклад. і голов. ред. В.Т. Бусел. Київ; Ірпінь: Перун, 2005. 1728 с.; 8. Коваленко О.О. Окремі проблеми здійснення соціального діалогу в Україні через призму характеристики його принципів у світлі входження до СС. Збірник наукових пращь Харківського національного університету ім. Г.С. Сковороди «Право». 2017. Вип. 28. С. 85-90; 9. Чанишева Г.І. Основні принципи соціального діалогу у сфері праці. Основні принципи соціального діалогу у сфері праці. Вісник південного регіонального центру Національної академії правових наук Украӥни. 2014. № 1. С. 100-106; 10. Про соціальний діалог в Україні: Закон України, 23 груд. 2010 р., № 2862-VI / Верховна Рада України. URL: http://zakon4.rada.gov.ua/laws/show/2862-17; 11. Конституція України: Закон України, 28 черв. 1996 р., № 254к/96-ВР / Верховна Рада України. URL: http://zakon4.rada.gov.ua/laws/show/254\%D0\%BA/96D0\%B2\%D1\%80; 12. Комітет 3 питань соціальної політики, зайнятості та пенсійного забезпечення провів «круглий стіл» на тему: «Соціальний діалог як інструмент взаємодії громадянського суспільства і держави». Інформаційне управління Апарату Верховної Ради України, 08 лист. 2017 р. / Верховна Рада України. URL: http://www.rada.gov.ua/news/Novyny/151210.html. 